Abstracta Iranica Abstracta Iranica

Revue bibliographique pour le domaine irano-aryen

Volume 25 | 2004

Comptes rendus des publications de 2002

\title{
« Muhammad Bāqir Šaftī (1180-1260/1766-1844) und die Isfahaner Gerichtsbarkeit ». Der Islam 79 (2002), pp. 240- 273.
}

\section{Christoph Werner}

\section{(2) OpenEdition}

1 Journals

\section{Édition électronique}

URL : http://journals.openedition.org/abstractairanica/4645

DOI : 10.4000/abstractairanica.4645

ISSN : 1961-960X

Éditeur :

CNRS (UMR 7528 Mondes iraniens et indiens), Éditions de l'IFRI

\section{Édition imprimée}

Date de publication : 15 mai 2004

ISSN : 0240-8910

Référence électronique

Christoph Werner, « « Muhammad Bāqir Šaftī (1180-1260/1766-1844) und die Isfahaner

Gerichtsbarkeit ». Der Islam 79 (2002), pp. 240- 273. », Abstracta Iranica [En ligne], Volume 25 | 2004

document 173, mis en ligne le 15 mars 2006, consulté le 25 septembre 2020. URL : http://

journals.openedition.org/abstractairanica/4645; DOI : https://doi.org/10.4000/abstractairanica.4645

Ce document a été généré automatiquement le 25 septembre 2020.

Tous droits réservés 


\title{
« Muḥammad Bāqir Šaftī (1180-1260/1766-1844) und die Isfahaner Gerichtsbarkeit ». Der Islam 79 (2002), pp. 240- 273.
}

\author{
Christoph Werner
}

1 Taking the well-known jurist and jurisprudent Muḥammad Bāqir al-Šaftī (d. 1260/1844) as an example, Schneider sheds new light on the judicial practice and its protagonists in Qajar Iran. Her major source on Šaftī and three of his verdicts which she discusses in detail is Tunakābunīs Qișās al-(Ulamā. The article sets out with a general introduction to the practice of law in the Qajar period, indebted to previous studies by Hamid Algar and Willem Floor, and also contains a biographical sketch of Šaftĩ. Schneider then presents and interprets three case studies, inserted as anecdotes by Tunakābunī mainly to illustrate Šaftī's cunning and resourcefulness. Using these anecdotes in a highly original way as a source on procedural aspects of legal practice, she notes in particular that Šaftĩ avoids formal steps as described in legal handbooks on gazavāt, nor does he justify or document his decisions with scriptural proofs or arguments of any kind. That this is not always the case, can be gleaned from another article on Šaftī - not noted by Schneider - by Seyyed Aḥmad Tūyserkānī, «EHtelāf-e naẓar-e do faqīh-e ham-'aṣr dar yek mas'ale-ye vaqfĩ : Mollā Aḥmad Narāqī va Ḥojj at alEslām Šaftī Eșfahānī ", Vaqf: Mīrāte-e jāvī̀ān, No. 19-20, vol. 5 (autumn \& winter 1376/1997), pp. 48-55, where an actual case led to a lengthy theoretical discussion. A separate discussion at the end is devoted to the assertion that Šaftĩ exercised the right of takfir, i.e. pronouncing someone an infidel. Schneider corrects this statement and presents the instances noted by Tunakābunī, where Šaftī issued verdicts of tafsīq (i.e. declaring someone to be sinful, that is not ( $\bar{a} d i l)$. 
INDEX

Thèmes : 4.2.1. Safavides et Qâjârs

\section{AUTEURS}

\section{CHRISTOPH WERNER}

Freiburg 